\title{
STUDY OF THE IMPACTS OF REGULATIONS AFFECTING THE ACCEPTANCE OF INTEGRATED COMMUNITY ENERGY SYSTEMS
}

\section{PRELIMINARY BACKGROUND REPORT}

Public Utility, Energy Facility Siting and Municipal Eranchising Regulatory Programs in Connecticut

\section{MASTER}

DUANE A. FEURER CLIFFORD L. WEAVER KEVIN C. GALLAGHER DAVID HEJNA

KEVIN J. RIEILEY

January, 1980
This book was prepared as an account of work sponsored by an agency of the United States Governenent. Neither the United States Government nor any agency thereof, nor any of their employees, makes an wartanty, express or implied, or assumes any legall liability or responsibility for the accuracy, represents that its use would not intringe privately owned rights. Referenes heress disclosed, of cominercial product, process, or service by trade name, trademark, manufacturer, or otherwise does not nocessarily constitute or imply its endorsement, recommendation, or favoring by the United States Grvernment or any agency thereof. The views and opinions of authors expressed herein do not
hecessarily state or reflect thiose of the United States Government or any agency therest.

WORK PERFORMED TNNER DOE CONTRACT NO.

$\mathrm{DE}-\mathrm{AC} 02-78 \mathrm{CS} 20289$

\footnotetext{
Ross, Hardies, O'Keefe, Babcock \& Parsons

One IBM Plaza

Suite 3100

Chicago, Illinois 60611
} 


\section{DISCLAIMER}

This report was prepared as an account of work sponsored by an agency of the United States Government. Neither the United States Government nor any agency Thereof, nor any of their employees, makes any warranty, express or implied, or assumes any legal liability or responsibility for the accuracy, completeness, or usefulness of any information, apparatus, product, or process disclosed, or represents that its use would not infringe privately owned rights. Reference herein to any specific commercial product, process, or service by trade name, trademark, manufacturer, or otherwise does not necessarily constitute or imply its endorsement, recommendation, or favoring by the United States Government or any agency thereof. The views and opinions of authors expressed herein do not necessarily state or reflect those of the United States Government or any agency thereof. 


\section{DISCLAIMER}

Portions of this document may be illegible in electronic image products. Images are produced from the best available original document. 


\title{
STUDY OF THE IMPACTS OF REGULATIONS \\ AFFECTING THE ACCEPTANCE OF \\ INTEGRATED COMMUNITY ENERGY SYSTEMS
}

\section{PRELIMINARY BACKGROUND REPORT}

Public Utility, Energy Facility

Siting and Municipal Franchising

Regulatory Programs in Connecticut

DUANE A. FEURER

CLIFFORD L. WEAVER

KEVIN C. GALIAGHER

DAVID HEJNA

KEVIN J. RIELLEY

January, 1980

WORK PERFORMED UNDER DOE CONTRACT NO.

\author{
$D E-A C 02-78 C S 20289$ \\ Ross, Hardies, O'Keefe, \\ Babcock \& Parsons \\ One IBM Plaza \\ Suite 3100 \\ Chicago, Illinois 60611
}

\section{UNITED STATES DEPARTMENT OF ENERGY}

Division of Buildings and Community Systems

under Contract No. DE-AC02-78CS20289

This report was prepared as an account of work sponsored by an agency of the United States Government.

Neither the United States nor any agency thereof, nor any of their employees, makes any warranty, expressed or implied, or assumes any legal liability or responsibility for any third party's use or the results of such use of any information, apparatus, product, or process disclosed in this report, or represents that its use by such third party would not infringe privately owned rights 


\section{ABSTRACT}

This report is one of a series of preliminary reports describing the laws and regulatory programs of the United states and each of the 50 states affecting the siting and operation of energy generating facilities likely to be used in Integrated Community Energy systems (ICES). Public utility regulatory statutes, energy facility siting programs, and municipal franchising authority are examined to identify how they may impact on the ability of an organization, whether or not it be a regulated utility, to construct and operate an ICES.

This report describes laws and regulatory programs in Connecticut. Subsequent reports will (1) describe public utility rate regulatory procedures and practices as they might affect an ICES, (2) analyze each of the aforementioned regulatory programs to identify impediments to the development of ICES and (3) recommend potential changes in legislation and regulatory practices and procedures to overcome such impediments. 


\section{CHAPTER I}

\section{INTRODUCTION}

One response to current concerns about the adequacy of the nation's: energy supplies is to make more efficient use of existing energy sources. The United states Department of Energy (DOE) has funded research, development and demonstration programs to determine the feasibility of applying proven cogeneration technologies in decentralized energy systems, known as Integrated Community Energy Systems (ICES), to provide heating, cooling and electrical services to entire "communities" in an energy conserving and economic manner.

The relevant "community" which will be appropriate for ICES development will typically consist of a combination of current energy "wasters"-- i.e., installations with large energy conversion facilities which now exhaust usable amounts of waste heat or mechanical energy -- and current energy users -- i.e., commercial or residential structures which currently obtain electricity and gas from a traditional centrai utility and convert part of it on customer premises to space heating and cooling purposes.

In most current applications, energy. conversion facilities burn. fuels such as coal, oil or natural gas to produce a single energy siream, such as process steam or electricity, for various industrial processes or for sale to other parties. However, the technology exists to produce 
more than one energy stream from most energy conversion processes so that the input of a given amount of fuel could lead to the production and use of far more usable energy than is presently produced. This technology is the foundation of the ICES concept. Current examples of the technology can be found on university campuses, industrial or hospital complexes and other developments where a central power plant provides not only electricity but also thermal energy to the reievant community.

It is generally assumed by DOE that ICES will be designed to produce sufficient thermal energy to meet all the demands of the relevant community. With a given level of thermal energy output, an ICES generation facility will be capable of producing a level. of electricity which may or may not coincide with the demand for electricity in the community at that time. Thus, an ICES will also be interconnected with the existing electric utility grid. Through an interconnection, the ICES will be able to purchase electricity when its community's need for electricity exceeds the amount can be produced from the level of operations needed to meet the community's thermal needs. In addition, when operations to: meet thermal needs result in generation of more electricity than necessary for the ICES community, the ICES will be able to sell excess electricity through the interconnection with the grid. 
ICES may take a variety of forms, from a single owner-user such as massive industrial complex or university campus where all energy generated is used by the owner without sales to other customers, to a large residential community in which a central power plant produces heat and electricity which is sold at retail to residents of the community. Since successful operation of an ICES presupposes that the ICES will be able to use or sell all energy produced, it can be anticipated that all ICES will at some point seek to sell energy to customers or to the electric utility grid from which the electricity will be sold to customers. By their very nature ICES are likely to be public utilities under the laws of many, or even all, states.

The Chicago law firm of Ross, Hardies, O'Keefe, Babcock \& Parsons has undertaken a contract with the Department of Energy to identify impediments to the implementation of the ICES concept found in existing institutional structures established to regulate the construction and operation of traditional public utilities which would normally be the suppliers to a community of the type of energy produced by an ICES.

These structures have been developed in light of. policy decisions which have determined that the most effective means of providing utility services to the public is by means of regulated monopolies serving areas large enough to permit economies of scale while avoiding wasteful 
duplication of production and delivery facilities. These existing institutional structures have led to an energy delivery system characterized by the construction and. operation of large central power plants, in many cases some distance from the principal population centers being served.

In contrast, effective implementation of ICES depends to some extent upon the concept of small scale operations supplying a limited market in an area which may already be served by one or more traditional suppliers of similar utility services. ICEs may in many instances involve both existing regulated utilities and a variety of nonutility energy producers and consumers who have not traditionally been subject to public uiility type regulation. It will also. require a variety of non-traditional relationships between existing regulated utilities and non-regulated energy producers and consumers.

Ross, Hardies, O'Keefe, Babcock \& Parsons is being assisted in this study by Deloitte Haskins \& Sells, independent public accountants, Hittman Associates, Inc., engineering consultants, and Professor Edmund Kitch, Professor of Law at the University of Chicago Law School.

The purpose of this report is to generally describe the existing programs of public utility regulation, energy facility siting and municipal franchising likely to relate to the develooment and operation of an ICES, and the construction of ICES facilities in connecticut.. Attention is 
given to the problems of the entry of an ICES into a market for energy which has traditionally been characterized by a form of regulated monopoly where only one utility has been authimplementation of the ICES concept and a series of recommendations for responding to those impediments. orized to serve a given area and to the necessary relationships between the ICES and the existing utility. In many jurisdictions legal issues similar to those likely to arise in the implementation of the ICES concept have not previously been faced. Thus, this report cannot give definitive guidance as to what will in fact be the response of existing institutions when faced with the issues arising from efforts at ICES implementation. 'Rather, this report is descriptive of present institutional frameworks as reflected in the public record.

Further reports are being prepared describing the determination and apportionment of relevant costs of service, rates of return and rate structures for the sale and purchase of energy by an ICES. Impediments presented by existing institutional mechanisms to development of ICES will be identified and analyzed. In addition to identifying the existing institutional mechanisms and the problems they present to implementation of ICES, future reports will suggest possible modifications of existing statutes, regulations and regulatory practices to minimize impediments to ICES. 
This report is one of a series of preliminary reports covering the laws. of all 50 states and the federal government. In addition to the reports on individual states, Ross, Hardies, o:Keefe, Babcock \& Parsons is preparing a summary report which will provide a national overvien of the existing regulatory mechanisms and impediments to effective implementation of the ICES concept and a series of recommendations for responding to those impediments. 
CHAPTER 2

REGULATION OF PUBLIC UTILITIES IN CONNECTICUT

I. PUBLIC AGENCIES WHICH REGULATE PUBLIC UTILITIES

The Connecticut statutes expressly provide for the regulation of public utilities. As of January 1, 1979, responsibility for the regulation of utilities is vested in the Public Utilities Control Authority (PUCA). Formerly such authority was exercised by the Public utilities commission which has been abolished and replaced by the PUCA. The Public Utilities Act provides that the PUCA is to consist of five members appointed by the governor with the advice and consent of both houses of the general assembly. I/ . It should be noted that statutory references to the Public Utilities Commission are deemed to mean the Public Utilities Control Authority. 2/

The statute gives only a minor role to local government in regulating public utilities. Local governments are authorized by statute to exercise control over the'placement of that equipment owned by public utilities which is not subject to the jurisdiction of the PUCA or Power Facility Evaluation Council. The relevant statute provides:

Except as provided.. . , the selectmen of any town, the common council of any city and the warden and burgesses of any borough shall, . . . . within their respective jurisdictions, have full direction and control over the placing, erection and maintenance of any such wires, conductors, fixtures, 
structures or apparatus, including the relocation or removal of the same and the power of designating the kind, quality and finish thereof, but no authority granted to any city or borough or a town planning, zoning, inland wetland, historic district, building, gas, water or electrical board, commission or committee created under authority of the general statutes or by virtue of any special act, shall be construed to apply to so much of the operations, plant, building, structures or equipment of any public service company as is under the jurisdiction of the public utilities commission, or the power facility evaluation council, but zoning commissions and inland wetland agencies may, within their respective municipalities, regulate and restrict the proposed location of any steam plant, gas plant, gas tank or holder, water tank or electric substation of any public service company not subject to the jurisdiction of the power facility evaluation council. $3 /$

The Public Utilities Act provides a specific

review process by which these local decisions may be appealed to the PUCA:

Any local body mentioned in this section and the appellate body, if any, may make all orders necessary to the exercise of such power, direction or control, which orders shall be made within thirty days of any application and shall be in writing and recorded in the records of their respective communities, and written notice of any order shall be given to each party affected thereby. Each such order shall be subject to the right of appeal within thirty days from the giving of such notice by any party aggrieved to the public utilities commission, which after rehearing upon notice to all parties in interest, shall have jurisdiction to affirm or modify or revoke such orders or make any orders in substitution thereof. 4 /

The jurisdictions of the PUCA and Power Facility Evaluation Council are so broad as to leave local governments 
with very little to regulate. The statute places the method of construction and the method of use of electric transmission lines within the exclusive jurisdiction of the PUCA. It provides that:

The commission shall have exclusive jurisdiction and direction over the method of construction or reconstruction in whole or in part of each system used for the transmission of electricity, with the kind, quality and finish of all materials, wires, poles, conductors and fixtures to be used in the construction and operation thereof, and the method of their use, including all plants and apparatus used for generating electricity located upon private property upon which there are conductors capable of transmitting electricity to other premises in such manner as to endanger any person or property. The commission may make any order necessary to the exercise of such power and direction, which order shall be in writing and entered in the records of the commission. 5/

The role of local governments in regulating public

utilities is confined to a limited exercise of police power. In a decision that invalidated a municipal ordinance requiring that two trainmen be on each car operating on a street railway extending through many communities, the court stated the following concerning the legislature's intent in creating the predecessor to the PUCA:

To promote uniformity in the regulation of public service corporations in the interest of the public welfare, safety, and convenience; to secure for such regulations obedience and respect like to that accorded the judgments of a court; to protect all public service corporations in the proper conduct of their business, affected as it is with a large public interest; and to provide an administrative agency with an organization trained and equipped to consider and determine 
all controversies and problems arising in connection with such corporations, and falling within the supervisory and regulatory power of government, the state created our Public Utilities Commission. None of these great interests would be served if each community retained the power of making such police regulations as each might deem proper. . .

Over certain matters of police power, wholly local, the state has left with the municipality either original or concurrent jurisdiction. Over regulations not exclusively local, those affecting the business as a whole, or affecting the public as a whole, and those which the nature of the business and the character of the regulation require should be under the single agency of the state, are by our act committed to the exclusive jurisdiction of the Public Utilities Commission. 6/

II. JURISDICTION OF THE PUCA

The PUCA has jurisdiction over all public service companies. The term "public service company" is defined to include any:

railroad, street railway, motor bus, electric, gas, telephone, telegraph, pipeline, sewage, water and community antenna television companies, owning, leasing, maintaining, operating, managing or controlling plants or parts of plants or equipment, and all express companies having special privileges on railroads or street railways within this state, but shall not include towns, cities, boroughs or any municipal corporation or department thereof, whether separately incorporated or not. If

The authority does not regulate heating or refrigeration service. $8 /$

Electric utility functions subject to regulation include generation, transmission, and distribution as provided in the following section: 
"[E] lectric company" includes every corporation, company, association, joint stock association, partnership or both, or lessee thereof, owning, leasing, maintaining, operating, managing or controlling poles, wires, conduits or other fixtures, along public highways or streets, for the transmission or distribution of electric current for sale for light, heat or power within this state, or engaged in generating electricity, to be so transmitted or distributed for such purpose. $9 /$

A "gas company" is defined as:

every corporation, company, association, joint stock association, partnership or person, or lessee thereof, owning, leasing, maintaining, operating, managing or controliing mains, pipes or other fixtures, in public highways or streets, for the transmission or distribution of gas for sale for heat or power within this state, or engaged in the manufacture of gas to be so transmitted or distributed for such purpose. 10/

Thus, the PUCA's jurisdiction extends to the manufacture, distribution and transmission of gas.

The definitions of electric and gas company state that there must be a sale for the utility to be subject to $11 /$ the PUCA's jurisdiction. Although these statutory definitions seem broad enough to extend PUCA's jurisdiction to all sales, including indirect sales, a PUCA spokesperson stated that indirect sales are not subject to regulation.

The statute does not expressly require that service be provided to the "public" or "for public use," or that utility facilities be "dedicated to public use." The general powers provision of the statute describing the authority of the agency mentions the "safety of the public" and requires 
that utility operations be "in the public interest." However, there are few judicial decisions which construe the meaning of "public." One case dealing with a trucking service defined a "common carrier" as:

'one who holds himself out to the public as, to carry persons or freight for hire,' and - . 'one whose business [it] is to carry, - - from one place to another the goods of all persons indifferently.'. . . The private carrier, on the other hand, carries only for persons with whom he has an initial contract. It is optional with him whether he will accept or reject any business that is offered to him. 14/

In that decision, a trucking company with four trucks and "a Iimited [but unspecified] number of customers," transported dresses under contract from various manufacturers and brought back dress material. $15 /$ The firm had verbal contracts with these customers under which it was obliged to carry dresses every day except sunday, no matter how slight the volume might be. $16 /$ Finding that there was no public undertaking to carry for all potential customers, the court held that the trucking company was not a common carrier so as to be subject to liability for loss of dresses in transportation.

The most useful precedents for construing the meaning of "public" are administrative decisions involving small water companies. In one such case, $\mathrm{Re} H o m e r \mathrm{H}$. Judd, a water service furnished by the owner of a tract of land to thirty-one cottage owners who had purchased lots from him was held not to be a public utility. The service was limited to 
the particular development with the understanding that the cottage owners would at some time in the future reimburse the tract owner for the cost of construction and operate the system for their mutual benefit. $19 /$ In distinguishing a public from a private water supply, the Public Utilities Commission explained that the former required "an intent that the distribution of water in the town, city, or borough. . . be broad, rather than restricted." $\frac{20 /}{}$ A similar case involved a water system owned and operated by a residential development company serving 101 customers of a summer colony. As in the Judd case, the Public Utility Commission took note that the water Iines were located entirely on private property. $22 /$ Holding the water service not to be a public utility, the Public Utility Commission concluded:

It is apparent that the patrons of Marjorie constitute a restrictive group; namely, the purchasers of property originally owned by Mr. Tuchmann. The question of whether or not a water utility has held itself out in fact, as willing to indiscriminately serve all members of the public reasonably within the reach of its services and facilities, appears to be a determinative factor as to whether or not a water system constitutes a public utility. Marjorie has not held itself out as willing to serve all members of the public, but serves only a restrictive group; namely, some of the owners of property in a specified tract of land originally owned by Mr. Tuchmann, with the right of selection retained by the owners of water utility. This commission's general jurisdiction only extends to public (water) utilities. 23/ 
The addition of only a single outside customer to those served in a restricted development may subject a utility service to regulation. One such case arose over a water system originally built to serve a large piece of property owned as a private residence. $\underline{24 /}$ The property was broken up into a housing development and the service expanded to supply twenty-two customers. $\frac{25 /}{}$. The water mains ran under streets that were private roads when the pipes were laid, but were now public highways. $26 /$ The Public Utilities commission explained:

\begin{abstract}
It may appear at first impression that the respondent serves only a restricted group -the purchasers of property in what was the original Stonecrest Manor estate. However, he has extended his service to a home owner outside of Stonecrest Manor. He claims that the former owner of this water system gave this customer outside of Stonecrest Manor permission to tie into the pipeline before the respondent took over this system. Nevertheless, by allowing this tie-in to his lines after he took possession of the water system, Mr. Polverari had, in effect, ratified this permission. Therefore, it appears to be the respondent's intent to serve all those members of the public reasonably within the reach of his services and facilities. 27/
\end{abstract}

In another case, however, the Public Utility Commission held that a company providing water service to only forty customers within a residential development was a public utility. $28 /$ The Commission stated: 
We say that the corporation is a public utility because it is holding itself out to supply water at uniform rates and terms to all purchasers of lots within the area represented by the development, is treating them uniformly and without discrimination and is using the public highways for that purpose, all attributes of a public utility service. While the corporation confines the distribution of water within the limits of the development, the present number of customers served, approximately 60 , and the potential number of cusomters, approximately 400 , represented by the lots in the development, constitute a large segment of the population in the area of the development, and the service which is supplied within the area of the development is "for general domestic use." . . . . [I]t is not necessary for the corporation to be engaged in distributing water within the entire limits of a given municipality but that a willingness to serve all of the people within a portion of a municipality will suffice. 29/

The most recent water case of this sort concerned a realty company that was a wholly-owned subsidiary of the Bridgeport Hydraulic Company, a regulated water utility. The realty company operated three separate water systems. One system in the town of Monroe served a residential development with fifteen houses and sixty-two additional service connections in unoccupied lots. ${ }^{32 /}$. The second system was designed to serve a Monroe public high school and the third system served ten customers in the town of westport. $33 /$. According to the Public Utility Commission:

It appears that the respondent has no proprietary interest in any of the residential developments it serves. Thus, this enterprise is unlike other types of small water systems whereby the developer of residential property installs a limited system designed to serve only the purchasers 
of dwellings which he constructs. . . . [I]t is the respondent's intent to provide water for compensation to all members of the public within the area of its facilities and to continue to expand its activities until such time as a franchise is obtained from the legislature authorizing Bridgeport Hydraulic to serve the town of Monroe, whereupon it is contemplated that all of the respondent's activities will be absorbed into the Bridgeport Hydraulic Company. 34/

Under these circumstances, the Commission held that the realty company was a public utility. $\underline{35 /}$ These cases indicate that if a service holds itself out as willing to serve an unrestricted group of consumers, the PUCA is likely to find that the service is a "public utility."

Since these cases were decided, a new provision amending the definition of "water company" has been added to the Public Utilities Act:
"water company" includes every corporation, company, association, joint stock association, partnership or person, or lessee thereof, owning, maintaining, operating, managing or controlling any pond, lake, reservoir, stream, well or distributing plant or system employed for the purpose of supplying water to fifty or more consumers;
"consumer" means any private dwelling, board- inghouse, apartment, store, office building, institution, mechanical or manufacturing establishment or other place of business or industry to which water is supplied by a water company. 36/

Water companies are the only class of public utility with a numerical standard for determining if a company is jurisdictional.

A PUCA spokesperson stated that the generation of energy for use solely by the party generating the energy is 
exempt from regulation. $\frac{37 /}{}$ This spokesperson also stated that the status of an entity producing energy solely for use by its tenants is uncertain under connecticut law and that PUCA resolves the issue of whether to assert jurisdiction over these entities on a case by case basis. A company cannot be a gas or electric public service company, however, if it does not use public streets or highways. $39 /$ No energy cooperatives are operating in Connecticut so the PUCA has not had reason to consider the extent of PUCA's jurisdiction over cooperatives. $\frac{40 /}{}$ Municipally-owned utilities and other public agencies are expressly exempted from regulation by the PUCA. $41 /$

III. POWERS OE THE PUCA

The general powers provision of the Public Utilities Act is as follows:

The Commission shall, so far as is practicable, keep fully informed as to the condition of the plant, equipment and manner of operation of all public service companies in respect to their adequacy and suitability to accomplish the duties imposed upon such companies by law and in respect to their relation to the safety of the public and of the employees of such companies. The commission may order such reasonable improvements, repairs or alterations in such plant or equipment, or such changes in the manner of operation, as may be reasonably necessary in the public interest. The general purposes of this section and sections 16-19, 16-25, 16-37, 16-43 and 16-47 are to assure to the state of Connecticut its full powers to regulate its public service corporations, to increase the powers of the public utilities commission and to promote local control of the public service corporations of this 
state, and said sections shall be so construed as to effectuate these purposes. $42 /$

The PUCA has power to regulate rates for sales to $43 /$

the public. However, this authority does not include the regulation of rates for sales of a party to another for resale to the public. $\stackrel{44 /}{ }$ Capitalization and issuance of securities are regulated by the PUCA. $\frac{45 /}{}$ The PUCA may prescribe a system of accounts for utilities and fix allowable rates for depreciation. $\frac{46 /}{4}$ Mergers and consolidations are subject to regulation. $47 /$ The PUCA has regulatory jurisdiction over affiliated interest transactions and over agreements between utilities. $\frac{48 /}{}$ No public service company may dispose of any essential part of its franchise, plant equipment, or other property without prior approval. Additionally, the consent of the PUCA Must be obtained before any public service corporation may close its operations. Another provision of the statute provides that: In the exercise of its powers. . . the authority shall examine and regulate the transfer of existing assets and franchises, the expansion of the plant and equipment of existing public service companies and the establishment of the level and structure of rates in accordance with the following principles:

(1) That there is a clear public need for the service being proposed or provided;

(2) that the public service company shall be fully competent to provide efficient and adequate service to the public in that such company is technically, financially and managerially expert and efficient; 
(3) that the authority and all public service companies shall perform all of their respective public responsibilities with economy, efficiency and care for the public safety, and so as to promote economic development within the state with consideration for energy conservation and the prudent management of the natural environment. . . 51/

The PUCA must consent, coordinate and integrate its actions with the Commission of Environmental Protection and the Power Facility Evaluation Council, which has exclusive jurisdiction over the location and type of electric facilities and over the location and type of modifications of such facilities. 2 / No special approval is required from the Public Utilities Control Authority for extension of service to new customers within the chartered area of a utility. The authority may order an electric company to extend lines in its chartered territory to previously unserved areas. $53 /$

IV. AUTHORITY TO ASSIGN RIGHTS IÓ PROVIDE SERVICE IN A GIVEN AREA

Unlike most state regulatory commissions, the PUCA does not issue certificates of public convenience and necessity except to motor common carriers, buses, and taxicabs. 54 The service areas of public utilities are regulated by legislative charter granting a franchise. The Connecticut General Assembly has followed the practice of awarding electric utility franchises for an indefinite duration while 
reserving the right to revoke the franchise for cause. Under a recently enacted statute, the power to revoke such a franchise has been granted to the PUCA.

The legislature may grant an exclusive franchise. In practice, this authority has been used to divide up the state into exclusive service areas for the provision of electric service. See Chapter 4 for additional discussion of franchises in Connecticut. There is no special statutory mechanism for the resolution of service area disputes by the PUCA. Because a utility has a duty to serve the public within its chartered territory, it may not abandon service to customers except where approved by the PUCA.

\section{APPEALS OF PUCA DECISIONS}

There is no express statutory requirement for requesting a rehearing before appealing a decision of the PUCA. The Public Utilities Act provides that:

Any company, town, city, borough, corporation or persons aggrieved by any order, authorization or decision of the authority, except an order, authorization or decision of the authority approving the taking of land, in any matter to which he or it was or ought to have been made a party, may appeal therefrom in accordance with the provisions of [The Administrative Procedure Act]. The party so appealing shall give bond to the state, with sufficient surety, for the benefit of the adverse party, in such sum as the authority fixes, to pay all costs in case he or it fails to sustain such appeal. 56/ 
The statute makes no provision for a rehearing before the PUCA. However, the Administrative Procedure Act requires that the appellant exhaust "all administrative remedies within the agency" and that he be aggrieved by a "final decision." $17 /$ a petition seeking judicial review must be filed in the superior court for Hartford County or for the judicial district in which the petitioner resides within 30 days after the mailing of the final decision. $\frac{58 /}{}$ The hearing on appeal is conducted by the court without a jury and is confined to the record. ${ }^{59 /}$ The record at the administrative decision making level may be supplemented in certain circumstances:

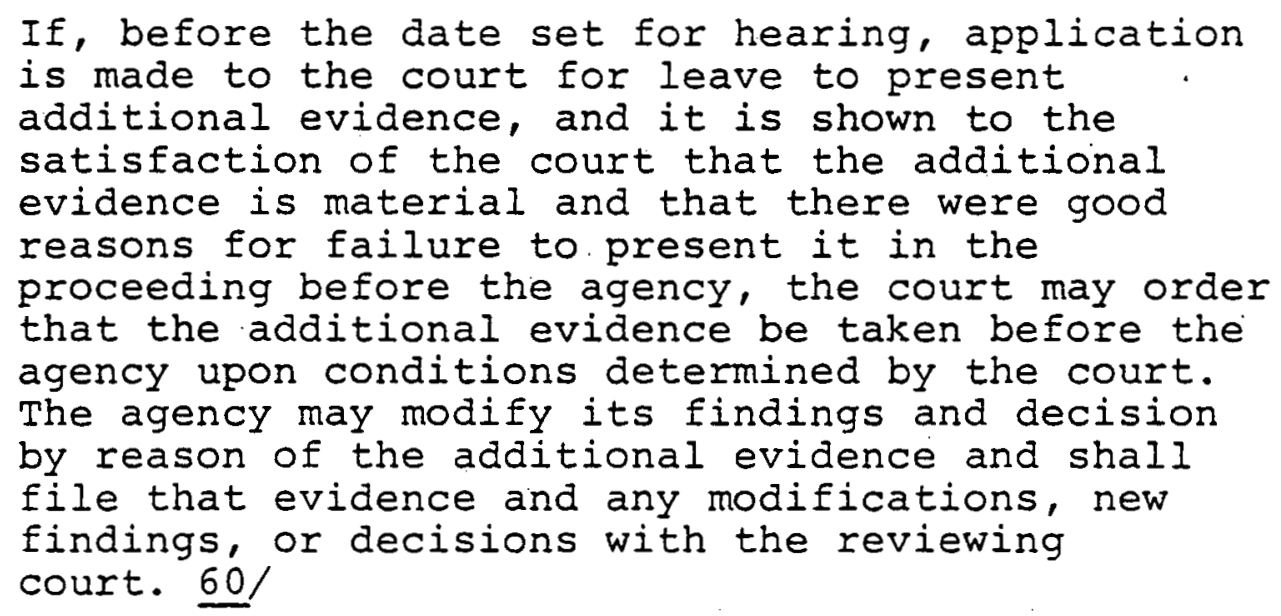

The court may not substitute its judgment for that of the agency as to evidence on questions of fact. The court may reverse or modify the PUCA's decision only if substantial rights of the appellant have been prejudiced by a decision which is: 
1. In violation of the constitutional or statutory provisions;

2. exceeds the PUCA's statutory authority;

3. is based upon unlawful procedure or other error of law; and

4. is clearly erroneous or arbitrary and capricious in view of the evidence. 61/

A final judgment of the court of common pleas may be appealed to the state supreme court. 


\section{FOOTNOTES}

1. Conn. Gen, Stat. Ann. $\$ 16-2(a),(b),(e)$ (West Supp. 1978).

2. Id. $\$ 16-1 a$.

3. Id. \$16-235 (West 1960).

4. Id., \$16-235 (West Supp. 1978).

5. Id. \$16-243 (West 1960).

6. Connecticut Co. V. City of New Haven, 103 Conn. 197, 130 A. 169, 174 (1925).

7. Conn. Gen. Stat. Ann. \$16-1 (West Supp. 1978).

8. Mr. R. Golden, Asst. Att'y Gen., Unit Head of Conn. PUCA, Telephone conversation, $8 / 24 / 78$.

9. Conn. Gen. Stat. Ann. \$16-1 (West Supp. 1978).

10. Ibid.

11. Ibid.

12. Mr. R. Golden, Asst. Att'y Gen., Unit Head, PUCA, Telephone conversation, $8 / 25 / 78$.

13. Conn. Gen. Stat. Ann. \$16-11. (West 1960).

14. Ace-High Dresses, Inc. v. J. C. Trucking Co., 122 Conn. 578,191 A. 536, 538 (1937).

15. Id. $191 \mathrm{~A}$ at 537-38.

16. Id. $191 \mathrm{~A}$ at 537.

17. Id. $191 \mathrm{~A}$ at 538-39.

18. Re Homer H. Judd, 58 P.U.R. N.S. 60 (1945).

19. Id. 58 P.U.R. N.S. at 62 .

20. Id. 58 P.U.R. N.S. at 63 . 
21. Water Committee V. Marjorie Manor, Inc. , 19 P.U.R. 3d $283(1957)$.

22. Id. 19 P.U.R. $3 d$ at 285.

23. Id. 19 P.U.R. 3d at 286 .

24. Re Stonecrest Manor Water Service, 13 P.U.R. 3d 123 (1956).

25. Id. 13 P.U.R. $3 d$ at 124 .

26. Id.

27. Id. 13 P.U.R. $3 d$ at 126 .

28. Re Ridgewood Park, Inc., 85 P.U.R. N.S. 392,398 (1950).

29. Id. 85 P.U.R. N.S. at 398-99.

30. Re B. H. Realty, Inc., 37 P.U.R. 3d 108, 109 (196I).

31. Id.

32. Id.

33. Id.

34. Id. 37 P.U.R. $3 d$ at $110-11$.

35. Id. 37 P.U.R. $3 d$ at 112 .

36. Conn. Gen. Stat. Ann. \$16-1 (West Supp. 1978).

37. Mr. R. Golden, Asst. Att'y Gen., Unit Head, PUCA, Telephone conversation, $8 / 25 / 78$.

38. Id.

39. Conn. Stat. Ann. \$16-1 (West Supp. 1978).

40. Mr. R. Golden, Asst. Att'y. Gen., Unit, Head, PUCA, Telephone conversation, $8 / 25 / 78$.

41. Conn. Gen. Stat. Ann. \$16-1 (West Supp. 1978).

42. Id. \$16-11 (West 1960).

43. Id. $\$ \$ 16-19$ to $16-19 e$ (West supp. 1978); $\$ \$ 16-20,-21$ TWest 1960). 
44. Mr. R. Golden, Asst. Att'y Gen., Unit Head, PUCA, Telephone conversation, 8/25/78.

45. Conn. Gen. Stat. Ann. $\$ 16-43$ (b) (West Supp. 1978).

46. Id. $\$ 16-66$.

47. Id. $\$ 16-43(1)$.

48. Mr. R. Golden, Asst. Att'y Gen., Unit Head, PUCA, Telephone conversation, $8 / 25 / 78$.

49. Conn. Gen. Stat. Ann. \$16-43(1) (West Supp. 1978).

50. Id. $\$ 16-46$.

51. Id. \$16-19e(a).

52. Id. $\$ 16-50 \times(a)$.

53. Id. \$16-261 (West 1960).

54. Id. $\$ 16-283$ (West supp. 1960); $\$ \$ 16-309,16-320$ (West Supp. 1978).

55. Id. \$16-10a (a) (West Supp. 1978).

56. Id. $\$ 16-35$.

57. Id. $\$ 4-183(\mathrm{a})$.

58. Id. $\S 4-183$.

59. Id. $\$ 4-183(\mathrm{~b})$.

60. Id. $\$ 4-183(\mathrm{e})$.

61. Id. \$4-183.

62. Id. $\$ 4-184$. 
CHAPTER 3

SITING OF ENERGY FACILITIES IN CONNECTICUT

I. PUBLIC AGENCIES WHICH ADMINISTER SITING LAWS

Connecticut's power plant siting legislation is contained in the Public Utility Enviromental Standards Act. I/ The Act creates a Power Facility Evaluation Council (Council) responsible for administering the siting statute. The council consists of the Commissioner of Enviromental Protection, or his designee; the Chairman of the Public Utilities Control Authority, or his designee; one designee of the Speaker of the House; one designee of the President Protempore of the Senate; and five members of the public, who are appointed by the governor, at least two of whom are experienced in the field of ecology, and not more than one of who has affiliation with any utility or governmental utility regulatory agency, or with any person owning, operating, controlling, or presently contracting with respect to an electrical or fuel transmission or generation facility: (discussed below). The public members serve staggered terms. The chairman of the council is "appointed by the governor from among the five public members, with the advice and consent of the house [and] senate," and serves as chairman at the pleasure of governor. $2 /$ subject to an appeal to the council, any town, city or borough zoning commission and inland wetland agency. may regulate and restrict the proposed location of a facility. under the Act. Such local bodies may make all orders necessary 
to the exercise of such power to regulate and restrict. Such orders must be made within thirty days of any application and must be in writing and recorded in the records of their respective communities. Written notice of any order is to be given to each party affected thereby. Each order is subject to the right of appeal within thirty days after the giving of notice by any party aggrieved to the council. The council has jurisdiction, in the course of any proceeding on an application for a certificate or otherwise, to affirm, modify or revoke such order or make any order in substitution thereof by a vote of six members of the council. 3 !

It is unclear to what extent the jurisdiction of state-level agencies is preempted by the council. The Act provides:

Notwithstanding any other provision of the general statutes to the contrary, except as provided in section 16-243 [giving the Public Utilities Control Authority exclusive jurisdiction over the method of construction of electric, transmission lines], the council shall have exclusive jurisdiction over the location and type of modifications of facilities subject to the provisions of subsection (d) of this section [the local zoning provision, discussed above]. In ruling on applications for certificates for facilities, the council shall give such consideration to other state laws and municipal regulations as it shall deem appropriate. Whenever the council certifies a facility pursuant to this chapter, such. certification shall satisfy and be in..lieu of all certifications, approvals and other requirements of state and municipal agencies in regard to any questions of public need, convenience and necessity for such facility. $4 /$ 
The question arises whether emission levels and enviromental standards fall within this category. The certificate issued by the council is called a "certificate of environmental compatability and public need" which would include environmental considerations, but the final phrase of this subsection, "in regard to any questions of public need, convenience and necessity for such facility," appears to limit the exclusiveness of the council's jurisdiction. The likely explanation is that, while the council is required to consider environmental compatability, its jurisdiction over such issues is not exclusive.

Agency spokesmen have expressed agreement that the Council does not pre-empt the authority of the Department of Environmental Protection with regard to issuance of environmental permits. $5 /$ one spokesman was of the opinion that the Department of Environmental Protection's authority was pre-empted by the council with regard to inland wetlands permits, tidal wetlands permits, and structures and dredging permits, but was not pre-empted in issuance of National Point Discharge Emission Source (NPDES) permits and air pollution stationary source permits issued by the state Department of Environmental protection. $6 /$ No spokesman was able to cite statutory, judicial, or other specific authority to support his view of pre-emption.

Whether or not the Department of Environmental Protection's jurisdiction is premernpted, the commissioner of Environmental protection has a seat on the siting council, and the council is required to solicit comments from the 
Department prior to commencing any hearing. ${ }^{7 /}$ In addition, the application is to include all federal, state, regional, district and municipal approvals which have been obtained or will be obtained, $\stackrel{8 /}{ }$ and the council is to "consult with and solicit written comments from" the Department of Environmental Quality, Public Utilities Control Authority, Department of Planning and Energy Policy, Department of Commerce, and Department of Transportation. $9 /$ The uncertainty in the scope and effect of the siting Act, and in council policies and procedures may be explained by the fact that only one power plant has been sited under the Public Utility Environmental Standards Act since its enactment in 1971, and no applications for power plants are currently before the council. $10 /$

II. SCOPE OF COUNCIL JURISDICTION

The Council has jurisdiction over the siting and modification of fuel, electric, and communication facilities as defined in the statute. 2 The term "facility" includes:

(1) An electric transmission line of a design capacity of sixty-nine kilovolts or more, including associated equipment;

(2) a fuel transmission facility, except a gas transmission line having a design capability of less than two hundred pounds per square inch guage pressure;

(3) any electric generating or storage facility. using any fuel, including nuclear materials, including associated equipment for furnishing electricity by electric utilities.

(4) such substations, switchyards, and other facilities which may have a substantial adverse environmental effect as the council established under section 16-50j may, by regulation, prescribe. 12/ 
The council has informally considered asking the Connecticut General Assembly for jurisdiction over liquified natural gas (LNG) storage facilities.

The type of ownership apparently makes no difference for purposes of the Council's siting jurisdiction. The statute provides that no "person" may construct a power facility project without Council approval. "Person" is defined as "any individual, corporation, joint venture, public benefit, corporation[sic], political subdivision, government agency, or authority, municipality, partnership, association, trust or estate and any other entity, public or private, however organized." $14 /$ Although the statute does not expressly mention cooperatives, the Council considers cooperatives subject to its siting regulation.

Agency spokesmen were more equivocal with respect to privately owned electric plants generating power for private use, but the statutory language seems broad enough to include such facilities. For facilities subject to the Council's jurisdiction, the statute specifies that, with limited exceptions regarding the exercise of eminent domain, no person may commence the preparation of a site for or commence the construction or the supplying of a facility without having first obtained a certificate of environmental compatibility and public need, if such facility is determined by the Council as having a substantial adverse environmental effect. If the council determines that a certificate is 
required for a facility, the facility must be built, maintained and operated in conformance with any terms, conditions, or Iimitations contained in the certificate. $16 /$

"Modification," as used in the statute, "means a significant change or alteration in the general physical characteristics of a facility."17/ The statute is interpreted by the council to cover replacement of existing facilities. 18/

There is a grandfather clause exempting electric generating plant and transmission line construction commenced before April 1, 1972.19/

The Council has power to promulgate regulations to carry out the provisions of the Public Utility Environmental Standards Act. $20 /$ Regulations issued by the Council are procedural and do not further define the jurisdiction of the council. One judicial decision has been reported discussing the Council's jurisdiction, but the court dealt only with the proper interpretation to be given the siting statute grandfather clause. 21/ There have been no cases involving the siting provisions. $22 /$

The Council has authority to continually monitor and regulate facilities after construction. $23 /$ The courts may issue injunctions and assess civil penalties to secure compliance. $24 /$

III. CERTIFICATION PROCESS

An application for an electric generating plant must include general items such as a description of the proposed electric generating or storage facility; a statement and full 
explanation of why the proposed facility is necessary; safety and reliability information; estimated cost information; available site information; design information; and a description of devices for mitigation of the effect of the operation of the facility on air and water quality, for waste disposal, and for noise abatement, and information on

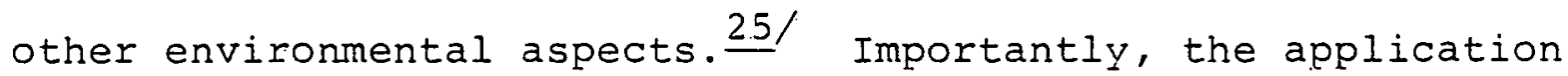
must also contain a justification for adoption of the site selected, including comparison with alternative sites. $26 /$ Apart from applications for specific sites, the Siting Act requires annual ten-year forecasts of loads and resources and biannual twenty-year forecasts of loads and resources are also required to be filed by any "person" engaged in generating electric power in the state. ("person"

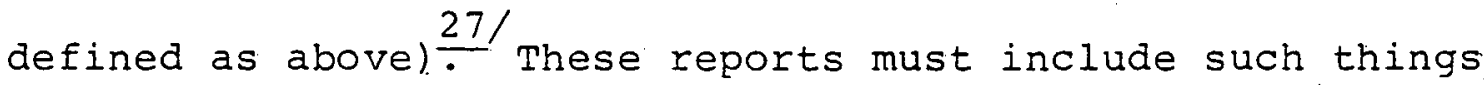
as a tabulation of estimated peak loads, resources and margins for each year; data on energy use and peak loads for the five preceding calendar years; a list of existing generating facilities in service; and a list of scheduled generating facilities: for which property has been acquired, for which certificates have been issued and for which certificate applications have been filed. The siting statute provides no penalty or procedure in case an application is submitted for a generating facility which was not anticipated in a prior forecast. The applicant must furnish notice and a copy of the application to other agencies or officials, and must provide 
for notice by newspaper publication. The other agencies include each municipality in which any portion of such facility is to be located; the attorney general; each member of the legislature in whose assembly or senate district the facility or any alternative location listed in the application is to be located; any agency, department or instrumentality of the federal government that has: jurisdiction, whether concurrent with the state or otherwise, over any matter that would be affected by such facility; and certain state departments and agencies noted in part I, above. $\frac{29 /}{}$

As noted in Part I, above, the council must consult with certain state agencies before proceeding to process an application, including the department of environmental protection, the state department of health, the council on environmental quality, the public utilities control authority, the department of planning and energy policy, the department of commerce and the department of transportation.

A public hearing must be held with respect to each application and for each significant amendment to an application. The council must promptly fix a date and location for a public hearing not less than 30 days nor more than 150 days after receipt of the application. The hearing is held in the county in which the facility or any part thereof is to be located. The council gives notice of the date and location of each hearing. $30 /$ 
The parties to a certification proceeding are to include:

(1) the applicant;

(2) each person entitled to receive a copy of the application under subsection (b) of section 16-501, if such person has filed with the council a notice of intent to be a party;

(3) any domestic or qualified nonprofit corporation or association formed in whole or in part to promote conservation or natural beauty, to protect the environment, personal health or biological values, to preserve historical sites, to promote consumer interests, to represent commercial and industrial groups or to promote the orderly development of the areas in which the facility is to be located, if it has filed with the council, within twenty days after the date given in the notice published under subsection (b) of section 16-501, as the date for filing of the application, a notice of intent to be a party; and

(4) such other persons as the council may at any time deem appropriate. 31/

The Council, at the certification proceeding; may provide for the grouping of parties with the same interests. An assistant or special assistant attorney general is appointed by the attorney general to act as counsel for the Council. Upon receipt of the application, the Council may employ independent consultants to "study and measure the consequences of the proposed facility on the environment." Any person may make a limited appearance at a certification hearing "prior thereto or within 30 days thereafter," and such person may file a written statement. 
The only report required of the Council is "an opinion stating in full its reasons for the decision." $\frac{33 /}{}$ council

decisions on electric generating plants and transmission lines must be rendered within ten months of the filing of an application. $34 /$

There is no statutory provision for a rehearing on an application by the Council. Judicial review may be obtained in accordance with the Connecticut Administrative Procedure Act. $35 /$ Any judicial review sought pursuant to the siting statute is privileged in respect to assignment for trial in the court of common pleas. $\stackrel{36 /}{ }$ To take an appeal, a petition must be filed within thirty days after mailing of the notice of the final decision. ${ }^{37 /}$ The appeal is conducted by the court without a jury and is confined to the record except in special circumstances. $\frac{38 /}{}$ The standard of review on appeal is set forth as follows:

The court shall not substitute its judgment for that of the agency as to the weight of the evidence on questions of fact. The court may affirm the decision of the agency or remand the case for further proceedings. The court may reverse or modify the decision if substantial rights of the appellant have been prejudiced because the administrative findings, inferences, conclusions, or decisions are: I) In violation of constitutional or statutory provisions; 2) in excess of the statutory authority of the agency; 3) made upon unlawful procedure; 4) affected by other error of law; 5) clearly erroneous in view of the reliable, probative, and substantial evidence on the whole record; or 6) arbitrary or capricious or characterized by abuse of 
discretion or clearly unwarranted exercise

of discretion. 39 !

IV. CERTIFICATION STANDARDS

Broad factors to be used by the council in con-

sidering applications are listed in the statement of legis-

lative finding and purpose of the siting Act. The purposes

of the Act are:

To provide for the balancing of the need for adequate and reliable public utility services at the lowest reasonable cost to consumers with the need to protect the environment and ecology of the state and to minimize damage to scenic, historic, and recreational values; to provide environmental quality standards and criteria for the location, design, construction and operation of facilities for the furnishing of public utility services at least as stringent as the federal environmental quality standards and criteria, and technically sufficient to assure the welfare and protection of the people of the state; to encourage research to develop new and improved methods of generating, storing and transmitting electricity and fuel and of transmitting and receiving television and telecommunications with minimal damage to the environment and other values described above; to require annual forecasts of the demand for electric power, together with identification and advance planning of the facilities needed to supply that demand and to facilitate local, regional, state-wide and interstate planning to implement the foregoing purposes. 40/

Specific criteria to be used by the council in evaluating a power plant application are also provided. The council. may not grant a certificate, unless it finds and determines:

1) A public need for the facility and the basis of the need;

2) the nature of the probable environmental impact, incliuding 
a specification of every significant adverse effect, whether alone or cumulatively with other effects, on, and conflict with the policies of the state concerning, the natural environment, ecological balance, public health and safety, scenic, historic and recreational values, forests and parks, air and water purity and fish and wildiffe; (3) why the adverse effects or conflicts are not sufficient reason to deny the application. $41 /$

Additional criteria are specified for electric and fuel transmission lines. The Council is required to determine :

- $\therefore$ in the case of an electric transmission line, (A') what part, if any, of the facility shall be located overhead, (B) that the facility conforms to a longrange plan for expansion of the electric power grid of the electric systems serving the state and interconnected utility systems and will serve the interests of electric system economy and reliability, and (C) that the overhead portions of the facility, if any, are consistent with the purposes of this chapter, with such regulations as the council may adopt pursuant to subsection (a) of section 16-50t, and with the Federal Power Commission "Guidelines for the Protection of Natural Historic Scenic and Recreational Values in the Design and Location of Rights-of-Way and Transmission Facilities" or any successor guidelines and any other applicable federal guidelines; 5) in the case of an electric or fuel transmission line, that the location of the line will not pose an undue hazard to persons or property along the area traversed by the line. $42 /$

The Council has power to promulgate specific siting rules and environmental standards, including regulations relating to:

1) Reliability, effluents, thermal effects, air and water 
emissions, protection of fish and wildife and other environmental factors; (2) the methodical upgrading or elimination of facilities over appropriate periods of time to meet the standards or regulations; and (3) the elimination of overhead electric transinission and distribution lines over appropriate periods of time in accordance with existing applicable technology and the need to provide electric service at the lowest reasonable cost to consumers. $43 /$

The Council, however, has not yet issued such regulations. There are no other standards that have been adopted in council rules, administrative decision, or court cases. The statute does not specify what weight is to be given to the recommendations of the other agencies that must be consulted. No standards are listed for overriding negative recommendations of other agencies. As noted above, the Department of Environmental Protection may have authority to withhold certain environmental permits. 
1. Conn. Gen. Stat. Ann. $\$ \$ 16-50 \mathrm{~g}$ to 16-50z (Supp. 1978).

2. Id. $\$ 16-50 j(b),(c)$.

3. Id. $\$ 16-50 \times(d)$.

4. Id. $\$ 16-50 \times(a)$.

5. Mrs. R. Curtis, Executive Assistant, Council, Telephone conversation, $8 / 16 / 78 ; \mathrm{Mr}$. R. Golden, Asst. Att" $y$ 'Gen." Counsel to Council, Telephone conversation, $8 / 16 / 178$; Mr. J. Klapt, Senior Environmental Analyst, Conn. Dept. of Environmental Protection, Telephone conversation 8/16/78.

6. Mr. J. Klapt, Senior Environmental Analyst, Conn. Dept. of Environmental Protection, Telephone conversation, 8/16/78.

7. Conn. Gen. Stat. Ann. $\$ 16-50 j(b)$, (f) (Supp. 1978).

8. Id. $\$ 16-50(e)(a)(z)(k)$

9. Id. $\$ 16-50 j$

10. Mrs. R. Curtis, Executive Assistant, Council, Telephone conversation, 8/16/78.

11. Conn. Gen. Stat. Ann. \$16-50k (a) (Supp. 1978).

12. Id. $\$ 16-50 i(a)$.

13. Mrs. R. Curtis, Executive Assistant, Council, Telephone Id. conversation, $8 / 16 / 78$.

14. Conn. Gen. Stat. Ann, \$16-50i (c) (Supp. 1978L.

15. Mrs. R. Curtis, Executive Assistant, Council, Telephone conversation, $8 / 16 / 78$.

16. Conn. Gen: Stat. Ann, \$16-50 (a) (Supp. 1978).

17. Id. $\$ 16-50 i(d)$.

18. Mrs. R. Curtis, Executive Assistant, Council, Telephone conversation, $8 / 16 / 78$.

19. Conn. Gen. Stat. Ann. \$16-50k (d) (Supp. 1978).

20. Id. $\$ \$ 16-50 j(e), 16-50 t$.

21. City of New Haven y. Public Utilities Commission, 165 Conn. 687, 345 A.2d 563 (19.74).

22. Mrs. R. Curtis, Executive Assistant, Council, Telephone conversation, $6 / 26 / 79$. 
23. Conn. Gen. Stat. Ann. \$16-50u (Supp. 1978).

24. Ibid.

25. Id. $\$ 16-50(e)(a)(2)$.

26. Ibid.

27. 1978 Conn. Legis. Sery,, Pub. Act 78-112, May 18, 1978 .

28. Ibid.

29. Conn. Gen. Stat. Ann. \$16-50 (el (b) (Supp. 1978).

30. Id. $\$ 16-50 \mathrm{~m}$ :

31. Id. $\$ 16-50 \mathrm{n}(\mathrm{a})$.

32. Id. \$16-50n (b-e).

33. Id. $\$ 16-50 p(a)$.

34. Ibid.

35. Id. $\$ \$ 4-183,16-50 q$ :

36. Ibid.

37. Id. $\$ 4-183(\mathrm{~b})$.

38. Id. \$4-.183(e), (f).

39. Id. $\$ 4-183(\mathrm{~g})$.

40. Id. $\$ 16-50 \mathrm{~g}$.

41. Id. $\$ 16-50 p(a)$.

42. Ibid.

43. Id. $\$ 16-50 t(a)$. 


\section{CHAPTER 4}

\section{$\frac{\text { FRANCHISING PUBLIC UTILITIES IN CONNECTICUT }}{7}$}

The connecticut state constitution is silent on the subject of public utility franchises and few connecticut statutes deal specifically with this subject. Most of the law governing franchises must be gleaned from case law, including many cases decided before 1900 .

\section{AUTHORITY TO GRANT FRANCHISES}

Connecticut municipalities appear to have no power to grant public utility franchises, or at least none applicable to the services that might be furnished by an energy generating facility. The granting of such franchises appears, rather, to be within the exclusive jurisdiction of the legislature. For example, in Robbins v. Hartford City Gaslight Co.. a defendant gas company had a franchise from the state "to lay down gas mains in the streets, highways and public grounds" of the city of wethersfield. The traditional form taken by state and local government in connecticut was described by one commentator in these words:

Not until 1951, when Rhode Island became the eighteenth state with effective constitutional home rule, did any New England state adopt it. This may seem rather strange in view of the town meeting tradition and the associated custom of vehemently proclaiming the virtues of local self government in New England. But the truth is that in many respects the local community of New England (excluding. Rhode Island) is less able to rule itself than many of its western counterparts. In New England the king of local government is the state legislature--only what the legislature grants to the supplicant community is permissible. 
Too often that grant is not a general law applicable to all towns or to a group of towns, but a special act which permits a $2 /$. particular town to take a specific action.

The effect of recent home rule legislation is discussed below.

In the past, connecticut courts have found that little legal authority was conferred in resolutions of municipal common councils purporting to grant companies the privilege to use the streets for public utility purposes. In the view of the courts, a "franchise" meant a property right that could be granted only by the state legislature.

An early case involving a toll bridge provides some explanation:

What are the rights of the plaintiffs?. They are derived from the grant of the legislature, and are what in law is known to be a franchise; and a franchise is an incorporeal hereditament known as a species of property, as well as any estate in lands. It is property, which may be bought and sold, which will descend to heirs, and may be devised. Its value is greater or less, according to the privilege granted to the proprietors. $3 /$

A municipality might grant to a utility a license to use the streets, but presumably it is a. license no stronger than any other license and could be revoked at any time (though unfortunately there are no cases precisely on the latter point). In Norwick Gas Light Co. v. Norwick City Gas Co. $\stackrel{4}{\text { a }}$ a case involving competing gas light companies and a purported exclusive grant, the court examined the legal effect of a common council resolution:

The resolution under which this right is claimed, purports to grant to Treadway and 
his assigns, for the period of fifteen years, the right to lay gas-pipes in the streets; and it declares that no other person or corporation shall, by consent of the common council, lay gas-pipes in said streets during that time. But the city does not own the streets.... And the right of way over them, being public to all who may have occasion to use them, and the only power of the city over them being given by their charter in order to regulate such use, it seems clear that the city can make no grant which shall convey to the grantee any interest in them, which can, in any proper sense, be deemed property. Besides, if the resolution of the court of common council be viewed in the light of a grant of an interest in the soil, it should have been perEected by a deed. No title, as such, can be transferred by a mere vote of a corporation, which will enable any one to hold any permanent interest in real estate.

But if the whole effect of the resolution be merely to license Treadway and his assigns to use the streets, so as to protect them from a. prosecution for a public nuisance for digging them up in order to lay down their pipes, it is obvious that it could only operate to protect themselves; and would give them no title by which they would be authorized to restrain the defendants from similar acts, provided those acts did not interfere with the works of the plaintiffs. $5 /$

Thus, the right to use the street was not exclusive and could not be since the soil of the streets was held to belong to adjacent property owners and not to the city.

In both Norwich and a Iater case involving competing water companies, the courts looked beyond whatever might have been said in the common council resolutions and instead turned their attention to the words used in the company charters granted by the legislature. ${ }^{7 /}$ Regardless of what power a municipality might have to permit the use of its streets, the courts have 
held that the license it could grant was not a franchise and did not create a contract:
... [I]nasmuch as Nathaniel Green had power to bind himself to furnish water for $a$. specified consideration, if the city had possessed power to bind itself in the manner proposed, there would have been no reason for the interference of the legisla- ture in the matter. The contract between an individual and the city would of neces- sity have been left to the parties, or to judicial arbitrament if they had disagreed. In the want of power upon the part of the city to give to Nathaniel Green a binding obligation to do what it desired to do, is found the only reason for the existence of the seventeenth section [of the company charter], to give the needed legislative sanction to the city's de- sire to grant, and to its act of granting, the exclusive use of the streets in return for the supply of water. The legislature having in effect authorized the city to make a contract which it desired to make, will not, cannot, now relieve it. Although the state is no party to, and has no interest whatever in, the subject- matter of a contract, if it volunteers to invest a creature of its own, otherwise powerless, with power to make it, the legislature is thereafter concluded in reference to it. 8/

In summary, a supplier of a public service appears to be on tenuous ground unless he is conferred a franchise in a charter granted by the legislature in a special act.

However, local governments do possess specific authority to regulate the location of utility fixtures along public streets and highways.

$[T]$ he selection of any town, the common council of any city and the warden and burgesses of any borough shall ... have full direction and control over the placing, erection and maintenance of any such wires, conducters, fixtures, structures or apparatus, including the removal and relocation of the same. . . but no authority granted to any city or borough. - . shall be construed as to apply to so much of the operations, plant, buildings, structures or equipment of any public service company or is under the jurisdiction of the division of public utility control. . . . $9 /$ 
Thus, while a franchise permitting operations must be granted by the state legislature, local governments are authorized to regulate location and manner of construction and maintenance of utility facilities. The franchise granted by the legislature does not entitle the franchisee to erect facilities free from local regulation. $10 /$ In addition, these powers cannot be exercised in such a way as to interfere with the jurisdiction of the Division of Public Utility Control. II. IMPLIED AUTHORITY TO GRANT FRANCHISES

The effect of recent Connecticut legislation providing for municipal home rule on local franchising powers has not yet been determined definitively by the courts. The state constitution contains a home rule powers provision which declares that, "The general assembly shall by general law delegate such legislative authority as from time to time it deems appropriate to towns, cities and boroughs relative to the powers, organization, and form of government of such political subdivisions. The first modern home rule statute was passed in Connecticut in the 1950's. $12 /$. The current version of the statute gives home rule municipalities the following specific powers:

(8) to lay out, construct, reconstruct, alter, maintain, repair, control and operate streets, alleys, boulevards, bridges, underpasses, sidewalks, curbs, gutters, public walks. .

(17) to regulate and prohibit the excavation, altering, use or opening of streets, sidewalks, highways, public places and grounds for public and private purposes and the location of any work or things thereon, whether temporary or permanent, upon or under the surface thereof; 
(18) to regulate the laying, location and maintenance of gas pipes, water pipes, drains, sewers, poles, wires, conduits and other structures in the streets and public places of the town, city or borough. 13/

This statutory language should be broad enough to provide local governments. with authority to grant franchises to use the streets. However, these provisions as they relate to local franchising powers have not been discussed in any reported judicial decisions.

A municipality may construct or establish its own publicly owned electric or gas plant without special approval by the legislature.

III. PROCEDURES FOR GRANTING FRANCHISES AND CRITERIA TO BE USED IN EVALUATING A FRANCHISE REQUEST

Except for a special statutory procedure applicable to bills submitted to the state legislature for the incorporation and franchise of water companies, there are no established procedures or criteria to be used in evaluating a franchise request. IV. CHARACTERISTICS OF A FRANCHISE

A. Duration and Termination

The modern custom of the Connecticut General Assembly has been to award electric utility franchises for an indefinite duration while reserving the power to revoke a franchise for cause. $16 /$ There are no judicial decisions imposing limits on the duration of a grant.

A recent statute expressly provides for termination of a public service franchise in case of unsatisfactory service. 
Power to revoke a franchise in such instances has been placed in the hands of the PUCA:

Whenever any person, firm or corporation, incorporated under the general statutes or any special act, is granted a franchise to operate as a public service company, as defined in section 16-1, and fails to provide service which is adequate to serve the public convenience and necessity to any town, city, borough, district or other political subdivision of the state, or any portion thereof, for a period of five years from the date of such franchise or from January 1 , 1961, whichever is later, the authority, on its own initiative, or upon complaint of any such town, city, borough, district, or other political subdivision, or on petition of not less than five per cent of the affected persons, but in no event more than one thousand persons, in any such town, city, borough, district or other political subdivison shall fix a time and place for a hearing to be held thereon. The authority shall give notice thereof to all parties in interest and shall make such further investigation into the alleged failure to provide such service as it deems necessary. If upon such hearing, said authority finds that the holder of such franchise has failed. to provide such service and that there is an immediate need for such service, it may revoke such franchise as to any such town, city, borough, district or political subdivision, or any portion thereof, or make such other order as may be necessary to provide such service. 18/

When a franchise is revoked, the PUCA may grant a franchise to another firm to provide such service if the need is immediate and the legislature is not in session:

If any such franchise is revoked, said authority ... may grant a franchise to any person, firm or corporation, incorporated under the general statutes or any special act, qualified and prepared to provide such services within a reasonable time, as determined by said authority provided the authority first finds there is an immediate need for such a franchise after a public hearing in the area to be served there- 
under. Such hearing shall be advertised at least twice prior thereto in a newspaper having a general circulation in each town of the area to be serviced by such franchise, once at least three days before said hearing, once at least fifteen days before said hearing, both advertisements to be at least ten days apart. Such franchise shall carry the same authority and powers and shall be subject to the same conditions and restrictions, if any, as the original franchise. 19/

B. Exclusivity

Exclusive franchises may be granted by the legislature. The General Assembly, in fact, has divided up virtually the whole state into exclusive franchise territories for purposes of electric service. $20 /$ This same point was made in an article by an early chairman of the former Public Utilities commission:

Public service or utility companies are organized and granted certain franchise rights and privileges as public agents to supply the public within their respective franchise territories with a specified public necessity. . . the supplying of what is defined as a public utility is in its nature monopolistic, and for this reason exclusive grants or franchises are issued, and operation thereunder is subject to public regulation. 21/

The legislature takes care to specify in the company charter exactly in which areas the supplier is authorized to operate. The PUCA does not issue certifica5es of public convenience and necessity to electric companies. Instead, service areas are controlied by legislative grant of charter. The franchising of steam heating companies in Connecticut appears to be more problematic. A number of steam heating companies were enfranchised at about the turn of the century. $\frac{22 /}{}$ None of these companies, however, is known still to exist. 23 . It is posible that the provision of largescale steam heating service has been largely taken over by 
municipally owned utilities. 24 Heating companies are not public service companies subject to regulation by the PUCA.

In the case of electric utilities, it is unnecessary that a company generate its power within its own service area. A statute passed in 1965 anticipated the need for the sharing of Eacilities and output associated with operating large nuclear power plants (usually constructed by a consortium of electric concerns):

Notwithstanding any limitation imposed by its charter, each domestic electric company is authorized and empowered to generate and transmit electric energy, and to acquire utility facilities necessary or convenient for the purposes of its electric utility business or undivided interests therein and to operate the same, anywhere within or without this state; provided nothing herein shall be construed to authorize such a company to sell electric energy in this state to any person, or within any area, except as otherwise authorized by its charter or the general statutes of this state. $26 /$

Normally it is necessary to revoke the franchise of a public service company or to dissolve and terminate it as a legal entity before another public service company may enter its service area. In one administrative case, a small water company petitioned the former Public Utilities Commission, first, to approve its termination and dissolution as a company, and second, to require a larger company, as a condition of exercising and continuing its franchise, to purchase the assets of the smaller company. Denying both requests, the Commission also responded negatively to an alternative proposal that the larger firm simply be permitted to take over service of the other's customers: 
The applicant, Gaylord Water Company, was given the franchise rights to serve the area in question with water. If it did not properly serve its people in its franchised area, the Commission would have the authority under \$16-20 of the Connecticut General Statutes to order it to furnish adequate service at just and reasonable rates. This section would not, as has been suggested, give the commission the power to order New Haven Water Company to furnish service while Gaylord remained the franchised company for this area. Not until Gaylord has obtained Commission approval for its dissolution and termination would this section be applicable to New Haven Water company. 28/

In limited instances, an electric utility may sell power outside of its own service area. A company may have charter authority to sell and deliver electricity to other power companies outside its territory and to enter into contracts for that purpose. In Wilson Point Property Owners Ass'n. v. Connecticut Light \& Power $c_{0} \cdot \frac{29}{1}$ the court held that the Public Utilities Commission could base a finding of the need for additional generating facilities on the requirements of an electric company serving territories outside its own specific franchise area. Regarding wholesale power, the court explained that, "...[T]he defendant's charter authority to furnish electric power to other companies for use in their respective franchise areas is, in a real sense, a franchise and, in effect, extends the franchise area of the defendant." $30 /$

Two statutes passed in the early part of the century elaborate the above exception. The statutes provide that 
under limited circumstances, electric companies empowered to sell at wholesale may sell at retail within another company's territory:

Any corporation authorized to sell and distribute electricity to electric light and power companies, railroad companies or electric companies may, within the territory within which it is authorized to transmit or convey such electricity for the purposes aforesaid and subject to the restrictions contained in section 16-245, sell, transmit, convey and deliver electricity generated within the state to any person or corporation desiring to use such electricity for the purpose of power and for any use incidental to or connected with manufacturing purposes. $33 /$

The procedure by which an electric company becomes authorized to sell directly to final users within another company's otherwise exclusive franchise area is as follows:

No such corporation shall exercise the privileges... within the territory where any corporation organized under any special act of the general assembly is engaged in the business of selling and distributing electricity for light, heat and power, until it has given notice of such intention to the commission [PUCA] with the names and location of the persons and corporations to whom it proposes to sell such electricity. The commission shali, upon receipt of such notice, assign a hearing thereon, giving reasonable notice thereof to any such corporation which is engaged in the business of supplying electricity for light, heat and power within the territory where the corporation giving such notice proposes to sell the same, and to the municipality wherein such territory is located, and the corporation giving such notice shall exercise within such territory the privileges conferred by section 16-244 except in cases where said commission then finds that the proposed action will materially impair the pubj.ic service or subject the public to any material 
inconvenience by reason of the erection of additional lines, poles, equipment or fixtures, or by reason of opening the highways or public places for the purpose of laying its wires, cables or conduits, or impair the financial condition of the corporation engaged in business therein so that it will be unable to furnish adequate service to the customers at such time being supplied by it and pay a reasonable dividend upon its investment within the state. 32/

A spokesman for the PUCA expressed the opinion that such permission to infringe upon another electric utility's service area would rarely if ever be granted today, it being the policy of the authority to adhere to established service boundaries.

Apparently none of the electric or heating company charters in Connecticut expressly purport to grant an "exclusive" franchise. Furthermore, there seems to be no modern court case deciding whether the legislature may grant to a public utility a franchise to serve an area where a franchise has already been granted to a prior company. However, there is a Iine of nineteenth century cases dealing with similar issues.

The earliest such case regarding exclusivity dealt with the right to construct locks upon a river for the purpose of collecting tolls. In Enfield Toll Bridge Co. v. Connecticut River Co.,, $34 /$ the court declared in dictum that:

Every grant is exclusive within the boundary of its obligation and extent, and may not be impaired, in the minutest degree. It is not 
a principle, that a grant may be infringed upon, if the variation be not great. As every variation violates, small injuries are as much prohibited as larger ones; and the least right is as anxiously protected as the greatest. . . When, however, a grant of any franchise is made, it will be carried no further than a just construction of it will warrant. Hence, a turnpike or a ferry may be granted at such distance from one that is prior in time, as the public good requires; if it appears on a just exposition of the first grant, that there is no interference within its limits. $3 \underline{5} /$

The court found that a legislative grant to the defendant to build locks infringed upon an earlier grant to the plaintiff $36 !$

to build locks upon that exact spot. "The court held, however, that plaintiff's laches in failing to construct the locks for twenty years barred an injunction against defendant's opera3.7

tions. In a later case, the same plaintiff was successful in

obtaining an injunction against infringement of its toll bridge franchise. Where plaintiff had been granted the exclusive right to erect a toll bridge across the connecticut River between two towns, the court held that a railroad bridge constructed one and one-half miles downstream violated plaintiff's property right. $39 /$ Another toll bridge case involved an 1818

General Assembly grant allowing construction of a bridge across the river between Hartford and East Hartford. " ${ }^{\prime}$ Although the 1818 grant ordered discontinuance of two existing municipal ferries operating at the site, the court held that it had not been expressly exclusive and did not bar a service later established by a private ferry company: 
... [I]t has been held to be the settled law throughout the country, that charters are to be construed most favorably for the state. ... [T] he grant of a franchise, as a bridge, canal, turnpike, railroad, or ferry, is a grant of right to construct and use the specific thing granted; and that, unless there be words restricting the legislature, they are at liberty to license other bridges, canals, turnpikes, railroads or ferries, according to the public exigency and their discretion, for it must be presumed that they are of opinion that such a necessity does exist. $41 /$

Three other nineteenth-century cases deal

with franchises not expressly made exclusive. In the first case, the General Assembly had incorporated the plaintiffs in 1824 for the purpose of building a turnpike along a certain route. ${ }^{42 \%}$ The court explained its reason for not enjoining the town of Lyme from completing a free public highway about seventy rods distant:

The new road complained of, is no part of the turnpike road, nor of the exact franchise granted to the turnpike company. Although it is nearly parallel with it, connecting two existing roads, it neither begins nor ends on the road, nor passes over any portion of it. It may somewhat, and very greatly, impair the value of the plaintiffs' franchise, as is the effect in numerous cases, where a parallel new road, canal, or bridge, or railroad, is made between the same points, or near them. If the public travel requires new or improved facilities, it is the right, if not the duty, of public servants to make them, or allow them to $b \in$ made. This is the well known condition upon which the plaintiffs took their charter; and they cannot complain, if "common convenience and necessity" require a new road.... In cases where a line of travel is given in a previous charter; or where some portion of the exact thing given before, is taken; it may be, that by reason of peculiar provisions in a charter, the legislature may be concluded; or 
if not, that damages may be assessed as in other cases where private property is taken for public use. The present case does not belong to this class. $43 /$

Another case involved a railroad seeking to enjoin three street railways with track in three different communities from connecting their lines to form one continuous line paralleling the $44 /$ railroad. The court upheld an injunction on the ground that the defendants had not obtained a finding from a superior court that the new parallel route was required in the public convenience and necessity, as required by statute. Nevertheless, the court denied a second request for an injunction on the ground that plaintiff's franchise gave it no right to be free from competition:

... [I]t is undoubtedly true that at common law the franchise of a ferry is held to be exclusive, even in cases where the words of the grant of the franchise do not import an exclusive right; and the same thing is held to be measurably true as to market, bridge, and turnpike franchises. . . . It is also undoubtedly true that the owner or holder of a franchise which the law holds to be exclusive, as was the case at common law generalIy with respect to market, ferry, bridge, and turnpike-road franchises, is held entitled to redress, by suit in his own name and behalf, against one who injuriously interferes with or disturbs this exclusive right. . . But the franchise of the plaintiff is not, under our law, exclusive in any such sense. The plaintiff has not, and does not claim to have, a monopoly, in this sense, of the business of carrying freight and passengers between Hartford and New Britain - . - Neither the plaintiff's charter, nor any law of this state, imposed a duty upon the defendants towards the plaintiff not to build a railway deviating from the chartered route, or not to build one beyond the chartered termini, or not to exercise powers and. rights not granted to them. 
The state or the stockholders may restrain the defendants from exercising powers not conferred by their charters, but this does not confer any right of action in this respect upon the plaintiff, unless its own legal or equitable rights are invaded by such exercise. 46 /

\section{Other Characteristics of a Franchise}

The franchise is not limited to the provision of any particular utility services. No mandatory franchise tax is required. There are no provisions in the law governing the abandonment of a franchise. However, the PUCA is authorized to revoke a franchise for failure on the part of the holder to serve the public convenience and necessity. $\stackrel{47 /}{ }$ It does not seem likely that the PUCA may authorize operation of a utility without a franchise. No. statute or judicial decision maintains that approval of a project by the Power Facility Evaluation Council would pre-empt the need for a franchise. A holder of a utility franchise can be required to relocate its facilities in public streets at its own expense when changes are required by public necessity. 
1. Robbins V. Hartford City Gaslight Co., 82 Conn. 394, 74 A. 113:(1909).

2. Lockard, Home Rule for Connecticut's Municipalities, 29 Conn. B. J. 51 (1955).

3. Enfield Toll Bridge Co. V. Hartford \& New Haven R. Co., 17 Conn. $40,60(1845)$.

4. Norwick Gas Light Co. v. Norwick City Gas Co., 25 Conn. 19, 31-32 (1856).

5. Id.

6. Enfield Toll Bridge Co. V. Hartford \& New Haven R. Co., 17 Conn. $40,60(1845)$.

7. Norwick Gas Light Co. V. Norwick City Gas Co.; 25 Conn. at 33-38; Citizens' Water Co. v. Bridgeport Hydraulic Co., 55 Conn. 1, 10 A. 170, 172-74 (1887).

'8. Citizens' water Co. V. Bridgeport Hydraulic Co., 55 conn. at 174 (emphasis added).

9. Conn. Gem Stat. Ann. \$16-235 (West Supp. 1979).

10. Hartford Electric Light Co. v. Water Resources Commission, 162 Conn. 89, 291 A.2d 721 (1971).

11. Conn. Const. art $10, \$ 1$.

12. 1957 Conn. Pub. Act 465 .

13. Conn. Gen. Stat. Ann. \$7-194(8), (17), (18), (West 1972).

14. Id. $\$ \$ 7-213$ to $7-215$.

15. Id. \$2-20A (West Supp: 1978).

16. Mr. W. Gundling, Asst. Att'y Gen., Counse], Public Utilities Control Authority (hereinafter PUCA) Telephone conversation $8 / 17 / 78$.

17. Conn. Gen. Stat. Ann. \$16-10A(a) (West supp. 19,78).

18. Ibid.

19. Id. \$16-10a (b). 
20. Mr. W. Gundling, Asst. Att'y Gen., Counsel to PuCA, Telephone conversation, $8 / 17 / 78$.

21. Higgins, Public Utility Regulation, 2 Conn. B. J. 94, 95 (1928).

22. See 24 Conn. Spec. Laws 255 (1943), for an example of a charter.

23. Mr. R. Golden, Asst. Att'y Gen., Unit Head, PUCA, Telephone conversation, $8 / 25 / 78$.

24. Id., Telephone conversation, $8 / 24 / 78$.

25. Conn. Gen. Stat. Ann. \$16-1 (West Supp. 1978).

26. Id. $\$ 16-246 \mathrm{~b}$.

27. Gaylord Water Co., 89 P.U.R. 3d 391, 392 (1971).

28. Id., 89 P.U.R. 3d at 392 .

29. Wilson Point Property Owners Ass'n v. Connecticut Light \& Power Co., 145 Conn. 243, 140 A.2d 874 (1958).

30. Id. 140 A. 2 d at 882 .

31. Conn. Gen. Stat. Ann. \$16-244 (West 1960).

32. Id. $\$ 16-245$.

33. Mr. W. Gundling, Asst. Att'y Gen., Counsel, PUCA, Telephone conversation, $8 / 18 / 78$.

34. Enfield Toll Bridge Co. v. Connecticut River Co.'

35. Id. 17 Conn. at 48 .

36. Id. 17 conn. at 49-50.

37. Id. 17 conn. at 51-52.

38. Enfield Toll Bridge Co. V. Hartfor \& New Haven R. Co.' 17 Conn. 40 (1845).

39. Id. 17 Conn. at 66-67. 
40. Hartford Bridge Co. v. Union Ferry Co., 29 Conn. 210 (1860).

41. Id. 29 Conn. at $223,225$.

42. Salem \& Hamburgh Turnpike Co. V. Town of Lyme, 18 Conn. 451 (1847).

43. Id. 18 Conn. at 456-57.

44. New England R. Co. V. Central Ry. \& Electric Co.', 69 Conn. 47, 36 A. 1061 (1897).

45. Id. 36 A. at $1062-63$.

46. Id. 36 A. at $1064-65$.

47. Conn. Gen. Stat. Ann. \$16-10a(a) (West Supp. 1978).

48. Connecticut Ry. and L. Co. V. New Britain Redev. Com'n, 161 Conn. $234(1971)$. (Utility could only be compensated for cost of the land and buildings which it vacated when the Redevelopment commission acquired it; not for utility's expenses in installing new facilities to handle what had been handled by the facilities acquired by the Redevelopment commission. 